\title{
ANALISIS FAKTOR-FAKTOR YANG MEMPENGARUHI PERILAKU KONSUMEN DALAM PENGAMBILAN KEPUTUSAN PEMBELIAN PRODUK ROTI ISI KRIM DURIAN (JORDAN BAKERY) DI DESA RANTAU SIALANG KECAMATAN SUNGAI KERUH
}

\author{
ANALYSIS OF FACTORS THAT AFFECT CONSUMER BEHAVIOR \\ IN MAKING DECISION TO PURCHASE DURIAN CREAM BREAD PRODUCT \\ (JORDAN BAKERY) IN RANTAU SIALANG VILLAGE SUNGAI KERUH \\ DISTRICT \\ Ellisyah Mindari \\ Sekolah Tinggi Ilmu Ekonomi Rahmaniyah \\ ellisyahmindari@gmail.com
}

Abstrak: Penelitian ini bertujuan untuk untuk menganalisa faktor-faktor yang mempengaruhi perilaku konsumen dalam pengambilan keputusan pembelian. Penelitian ini menggunakan pendekatan kuantitatif. Dalam penarikan sampel yang peneliti lakukan dengan menggunakan rumus slovin. Sampel dalam penelitian ini adalah warga Desa Rantau Sialang dengan jumlah responden sebanyak 97 orang. Metode analisis dengan menggunakan alat analisis dengan bantuan program IBM SPSS Statistics 24. Hasil penelitian ini menunjukan bahwa ada pengaruh yang positif dan signifikan faktor budaya, faktor sosial, faktor pribadi dan faktor psikologis secara bersama-sama terhadap keputusan pembelian dengan nilai $F_{\text {hitung }}(146,337)>F_{\text {tabel }}(2,471)$ dan nilai signifikan 0,000. Selanjutnya berdasarkan hasil uji $t$ untuk variabel faktor budaya $\left(X_{1}\right)$ diperoleh nilai thitung $(-0,119)<$ nilai tabel $(-1,985)$, nilai signifikan $t$ sebesar 0,905 $>$ nilai $\alpha(0,05)$, sehingga dapat disimpulkan bahwa faktor budaya $\left(X_{1}\right)$ secara parsial tidak berpengaruh secara signifikan terhadap keputusan pembelian (Y). Sementara itu, variabel faktor sosial $\left(X_{2}\right)$ diperoleh nilai $t_{\text {hitung }}(4,771)>$ nilai $_{\text {tabel }}$ $(1,985)$ dan nilai signifikan $t$ sebesar $0,000<$ nilai $\alpha(0,05)$; variabel faktor pribadi $\left(X_{3}\right)$ diperoleh nilai $t_{\text {hitung }}(10,631)>$ nilai $t_{\text {tabel }}(1,985)$ dan nilai signifikan $t$ sebesar 0,000 < nilai a $(0,05)$; variabel faktor psikologis $\left(X_{4}\right)$ diperoleh nilai $t_{\text {hitung }}(-2,713)>$ nilai tabel $(-1,985)$ dan nilai signifikan $t$ sebesar $0,008<$ nilai $\alpha$ $(0,05)$. Dengan hasil tersebut berarti bahwa faktor sosial $\left(X_{2}\right)$, faktor pribadi $\left(X_{3}\right)$ dan faktor psikologis $\left(X_{4}\right)$ secara parsial berpengaruh secara signifikan terhadap keputusan pembelian $(Y)$.

Kata kunci: Budaya, Sosial, Pribadi, Psikologis dan Keputusan Pembelian.

Abstract: This study aims to analyze the factors that affect consumer behavior to purchase decisions. This study using a quantitative approach. Sampling in this study uses the Slovin Formula. The sample in this study were 79 citizens of Rantau Sialang Village. The analysis method uses analytical tools with the help of 
The IBM SPSS Statistics 24 Program. The results of this study indicate that there is a positive and significant effect on cultural factors, social factors, personal factors and psychological factors together on purchase decisions with a value of $F_{\text {count }}(146,337)>F_{\text {table }}(2,471)$ and a significant value of 0,000. Furthermore, based on the results of the t-test for the variable cultural factors $\left(X_{1}\right)$ obtained $t_{\text {count }}(-0.119)<t_{\text {table }}$ value (-1.985), a significant value of $t$ is $0.905>\alpha$ value (0.05), so it can be concluded that the cultural factor $\left(X_{1}\right)$ partially does not significantly affect on purchase decisions (y). Meanwhile, social factor variables $\left(X_{2}\right)$ obtained $t_{\text {count }}(4.771)>t_{\text {table }}(1.985)$ and significant value of $t$ is $0.000<\alpha$ value (0.05); personal factor variable $\left(X_{3}\right)$ is obtained $t_{\text {count }}(10,631)>t_{\text {table }}$ (1.985) and significant value of $t$ is $0.000<\alpha$ value (0.05); psychological factor variable $\left(X_{4}\right)$ obtained tcount (-2.713) $>t_{\text {table }}(-1.985)$, significant value of $t$ was $0.008<\alpha$ value (0.05). With these results it means that social factors $\left(X_{2}\right)$, personal factors $\left(X_{3}\right)$ and psychological factors $\left(X_{4}\right)$ partially effect significantly on purchase decisions (y).

Keywords: Culture, Social, Personal, Psychological and Purchase Decision.

\section{LATAR BELAKANG}

Perkembangan teknologi dan
industri membawa dampak bagi
kehidupan manusia terutama dunia
usaha. Persaingan yang ketat terjadi
antara pengusaha untuk memperebutkan
pangsa pasar yang ada. Semakin
luasnya persaingan mengharuskan
pengusaha lebih jeli dalam
mengantisipasi keadaan pasar.

Pemasaran sebagai salah satu kegiatan yang dilakukan dalam menghadapi persaingan untuk mendapatkan laba. Pengusaha dituntut mengembangkan produknya, menetapkan harga, mengadakan promosi dan mendistribusikan produk dengan efektif.

Perusahaan umumnya mengalami kesulitan untuk memahami perilaku konsumen secara tepat dan benar karena banyaknya faktor yang mempengaruhi perilaku konsumen. Abdullah dan Tantri (2012: 134) mengemukakan bahwa perilaku pembeli dipengaruhi oleh empat faktor utama: budaya (kultur, subkultur dan kelas sosial), sosial (kelompok acuan, keluarga serta peran dan stasus), pribadi (umur dan tahap siklus hidup, pekerjaan, keadaan ekonomi, gaya hidup serta kepribadian dan konsep diri) dan psikologis (motivasi, persepsi, pengetahuan serta keyakinan dan sikap).

Konsumen
cenderung lebih individualis dan
menuntut sesuatu hal yang lebih
bersifat pribadi atau personal. Untuk
memenuhi kebutuhan tersebut
perusahaan dituntut
memahami keinginan dan kebutuhan konsumen agar tetap bertahan. Diterima tidaknya produk yang dijual sangat tergantung pada persepsi konsumen atas produk tersebut. Jika konsumen merasa produk tersebut dapat memenuhi kebutuhan dan

Jurnal Ekonomika Volume XI Nomor 2 Juni 
keinginannya pasti konsumen akan membeli produk tersebut. Seperti sekarang ini persaingan di dunia kuliner semakin ketat, khususnya persaingan makanan ringan. Fakta memperlihatkan penjualan makanan terus meningkat. Kondisi ini membuat produsen semakin meningkatkan inovasi dengan meluncurkan produkproduk baru untuk meningkatkan penguasaan pasar.

Salah satu produk makanan ringan yang banyak diminati oleh masyarakat Desa Rantau Sialang Kecamatan Sungai Keruh adalah roti isi krim durian yang diproduksi oleh Jordan Bakery. Roti ini mudah didapatkan, bisa dikonsumsi semua usia dan harganya yang ekonomis. Masyarakat Desa Rantau Sialang didominasi oleh masyarakat dengan kehidupan yang sederhana dengan pendapatan rendah.

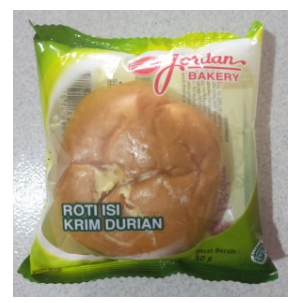

Gambar 1

Roti Isi Krim Durian (Jordan Bakery)

Umar Khasan (2018) melakukan penelitian di Hypermart Bangkalan dengan tujuan menganalisis faktorfaktor yang mempengaruhi perilaku konsumen dalam pengambilan keputusan pembelian white coffee. Hasil penelitiannya menunjukkan bahwa budaya, tingkat pendidikan, usia dan jenis kelamin mempengaruhi keputusan pembelian. Pendapatan tidak berpengaruh dalam pengambilan keputusan pembelian white coffee.

Penelitian yang dilakukan oleh Suprihati dan Wikan Budi Utami (2015) di Kelurahan Gonilan Kabupaten Sukoharjo dengan tujuan pertama untuk mengetahui apakah ada beda nyata atau signifikan antara faktor umur, pendidikan, pekerjaan, pendapatan dan faktor gengsi terhadap perilaku konsumen dalam keputusan pembelian mobil pribadi dan tujuan kedua untuk mengetahui seberapa kuat tingkat hubungan yang terjadi antara faktor umur, pendidikan, pekerjaan, pendapatan dan faktor gengsi terhadap perilaku konsumen dalam keputusan pembelian mobil pribadi. Hasil penelitian ini menyimpulkan bahwa tidak ada perbedaan yang nyata antara golongan umur, pendidikan, pekerjaan dan faktor gengsi terhadap perilaku konsumen dalam keputusan pembelian mobil pribadi. Hanya ada perbedaan yang nyata antara pendapatan terhadap perilaku konsumen dalam keputusan pembelian mobil pribadi.

Hendry Wijaya, Yeni Marsih dan Rini Anggraini (2018) melakukan penelitian dengan tujuan untuk mengetahui pengaruh faktor psikologis terhadap keputusan pemilihan biro perjalanan umroh pada PT. Namirah Angkasa Jayatama (NAJA) Tour \& Travel Sekayu. Hasil penelitian menunjukkan bahwa variabel faktor psikologis mempengaruhi keputusan pemilihan sebesar 7,9\%, sedangkan sisanya $92,1 \%$ dipengaruhi oleh variabel yang tidak diteliti dalam penelitian tersebut.

Penelitian yang saya lakukan bertujuan untuk menganalisa faktorfaktor yang mempengaruhi perilaku konsumen dalam pengambilan 
keputusan pembelian produk roti isi krim durian (jordan bakery) di Desa Rantau Sialang Kecamatan Sungai Keruh, baik secara parsial maupun secara bersama-sama.

\section{TINJAUAN PUSTAKA}

$\underline{\text { Pemasaran }}$

Pemasaran menurut Sumarwan (2014: 17) adalah suatu proses bagaimana mengidentifikasi kebutuhan konsumen kemudian memproduksi barang atau jasa yang dibutuhkan konsumen tersebut dan meyakinkan konsumen bahwa mereka membutuhkan barang atau jasa tersebut, sehingga terjadi transaksi atau pertukaran antara produsen dengan konsumen. Kemudian Abdullah dan Tantri (2012: 22) mengemukakan bahwa pemasaran adalah proses sosial dan manajerial di mana individu dan kelompok mendapatkan kebutuhan dan keinginan mereka dengan menciptakan, menawarkan dan menukarkan produk yang bernilai satu sama lain.

Dari sudut pandang manajerial, pemasaran menurut Kotler dan Keller (2009: 32) adalah fungsi organisasi dan serangkaian proses untuk menciptakan, mengomunikasikan dan menghantarkan nilai kepada pelanggan dan untuk mengelola hubungan pelanggan dengan cara yang menguntungkan organisasi dan pemegang kepentingannya.

\section{Manajemen Pemasaran}

Menurut Daryanto (2011: 6), manajemen pemasaran adalah analisis, perencanaan, implementasi dan pengendalian program yang dirancang untuk menciptakan, membangun dan mempertahankan pertukaran yang menguntungkan dengan target pembeli untuk mencapai sasaran organisasi.

Shinta (2011: 1) mengemukakan bahwa manajemen pemasaran adalah suatu usaha untuk merencanakan, mengimplementasikan (yang terdiri dari kegiatan mengorganisasikan, mengarahkan, mengkoordinir) serta mengawasi atau mengendalikan kegiatan pemasaran dalam suatu organisasi agar tercapai tujuan organisasi secara efisien dan efektif. Assauri (2010: 12) menyatakan bahwa manajemen pemasaran merupakan kegiatan penganalisisan, perencanaan, pelaksanaan dan pengendalian programprogram yang dibuat untuk membentuk, membangun dan memelihara, keuntungan dari pertukaran melalui sasaran pasar guna mencapai tujuan organisasi (perusahaan) dalam jangka panjang.

$\underline{\text { Keputusan Pembelian }}$

Keputusan pembelian melalui proses jauh sebelum pembelian sesungguhnya dan bukan berarti berakhir ketika pembelian berlangsung, akan tetapi proses tersebut tetap berlanjut dalam waktu yang lama setelah pembelian. Konsumen dalam proses keputusan pembelian untuk memenuhi kebutuhan melalui 3 tahap utama, yaitu sebelum pembelian, pembelian (konsumsi) dan setelah pembelian.

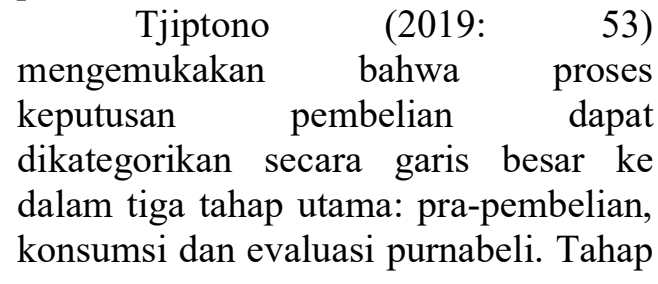


pra-pembelian mencakup semua aktivitas konsumen yang terjadi sebelum terjadinya transaksi pembelian dan pemakaian produk. Tahap ini meliputi tiga proses, yakni identifikasi kebutuhan, pencarian informasi dan evaluasi alternatif. Tahap konsumsi merupakan tahap proses keputusan konsumen di mana konsumen membeli dan menggunakan produk atau jasa. Sedangkan tahap evaluasi purnabeli adalah tahap proses pembuatan keputusan konsumen sewaktu konsumen menentukan apakah ia telah membuat keputusan pembelian yang tepat.

Menurut Abdullah dan Tantri (2012: 129), ada lima tahap dalam proses keputusan pembelian: pengenalan masalah, pencarian informasi, evaluasi alternatif, keputusan pembelian dan perilaku purnabeli. Tahapan dalam proses keputusan pembelian yang sama juga dikemukakan oleh Kotler dan Keller (2009: 184), lima tahap tersebut adalah pengenalan masalah, pencarian informasi, evaluasi alternatif, keputusan pembelian dan perilaku pascapembelian.

\section{$\underline{\text { Perilaku Konsumen }}$}

Menurut Tjiptono (2019: 120),
perilaku konsumen mencakup keputusan konsumen dalam hal pembelian, pemakaian dan penghentian pemakaian produk dan jasa. Perilaku konsumen meliputi beraneka bentuk produk dan dapat melibatkan banyak orang dengan berbagai peran berbeda. Sumarwan (2014: 5) mengemukakan bahwa perilaku konsumen adalah semua kegiatan, tindakan serta proses psikologis yang mendorong tindakan tersebut pada saat sebelum membeli, ketika membeli, menggunakan, menghabiskan produk dan jasa setelah melakukan hal-hal di atas atau kegiatan mengevaluasi. perilaku konsumsen menurut Daryanto (2010: 221) adalah tingkah laku dari konsumen, dimana mereka dapat mengilustrasikan pencarian untuk membeli, menggunakan, mengevaluasi dan memperbaiki suatu produk dan jasa mereka.

Kotler dan Keller (2009: 166) mendefinisikan perilaku konsumen sebagai studi tentang bagaimana individu, kelompok dan organisasi memilih, membeli, menggunakan dan bagaimana jasa, ide, atau pengalaman untuk memuaskan kebutuhan dan keinginan mereka.

Peter dan Olson (2014: 6) menyatakan bahwa perilaku konsumen melibatkan pemikian dan perasaan yang mereka alami serta tindakan yang mereka lakukan dalam proses konsumsi. Hal itu juga mencakup segala hal pada lingkungan yang mempengaruhi pemikiran, perasaan dan tindakan tersebut. Hal ini termasuk komentar konsumen lainnya, iklan, informasi harga, pengepakan, penampilan produk, blogs dan lainnya. Perilaku konsumen bersifat dinamis (pemikiran, perasaaan dan tindakan individu konsumen, kelompok target dan masyarakat luas berubah secara konstan), perilaku konsumen melibatkan interaksi (antara pemikiran seseorang, perasaan dan tindakan serta lingkungan), perilaku konsumen melibatkan pertukaran antar manusia (seseorang memberikan sesuatu yang bernilai kepada yang lainnya dan menerima sesuatu sebagai imbalannya). Jadi perilaku konsumen adalah tindakan personal yang dilakukan oleh konsumen dalam proses 
keputusan pemenuhan kebutuhan akan produk dan atau jasa.

Faktor-faktor yang Mempengaruhi Perilaku Konsumen

Menurut Kotler dan Amstrong (2008: 159), pembelian konsumen sangat dipengaruhi oleh karakteristik budaya, sosial, pribadi dan psikologis. Biasanya pemasar tidak dapat mengendalikan faktor-faktor semacam itu, tetapi mereka harus memperhitungkannya.

1. Faktor Budaya

Faktor budaya mempunyai pengaruh yang luas dan mendalam pada perilaku konsumen. Pemasar harus memahami peran yang dimainkan oleh: Budaya (kumpulan nilai dasar, persepsi, keinginan dan perilaku yang dipelajari oleh anggota masyarakat dari keluarga dan instusi penting lainnya), Sub budaya (kelompok masyarakat yang berbagi sistem nilai berdasarkan pengalaman hidup dan situasi yang umum) dan Kelas Sosial (pembagian yang relatif permanen dan berjenjang dalam masyarakat di mana anggotanya berbagi nilai, minat dan perilaku yang sama).

\section{Faktor Sosial}

Perilaku konsumen juga dipengaruhi oleh faktor-faktor sosial, seperti Kelompok Acuan (semua kelompok yang mempunyai pengaruh langsung atau tidak langsung terhadap sikap atau perilaku orang tersebut. Kelompok acuan memperkenalkan perilaku dan gaya hidup baru kepada seseorang, mereka mempengaruhi sikap dan konsep diri, dan mereka menciptakan tekanan kenyamanan yang dapat mempengaruhi pilihan produk dan merek), Keluarga (organisasi pembelian konsumen yang paling penting dalam masyarakat dan anggota keluarga merepresentasikan kelompok referensi utama yang paling berpengaruh) serta Peran dan Status (orang memilih produk yang mencerminkan dan mengkomunikasikan peran mereka serta status aktual atau status yang diinginkan dalam masyarakat).

\section{Faktor Pribadi}

Keputusan pembeli juga dipengaruhi oleh karakteristik pribadi seperti Usia dan Tahap Siklus Hidup (orang mengubah barang dan jasa yang mereka beli sepanjang hidup mereka. Selera makanan, pakaian, perabot dan rekreasi sering berhubungan dengan usia. Pembelian juga dibentuk oleh tahap siklus hidup keluarga atau tahap-tahap yang dilalui keluarga ketika mereka menjadi matang dengan berjalannya waktu), Pekerjaan (pekerjaan seseorang mempengaruhi barang dan jasa yang mereka beli), Situasi Ekonomi (situasi ekonomi seseorang akan mempengaruhi pilihan produk. Beberapa pemasar menargetkan konsumen yang mempunyai banyak uang dan sumber daya, menetapkan harga yang sesuai), Gaya Hidup (pola hidup seseorang yang diekspresikan dalam kegiatan, minat dan pendapatnya. Konsep gaya hidup dapat membantu pemasar memahami nilai konsumen yang berubah dan bagaimana gaya hidup mempengaruhi perilaku pembelian) serta Kepribadian dan Konsep Diri (kepribadian mengacu pada karakteristik psikologi unik seseorang yang menyebabkan respons yang relatif konsisten dan bertahan lama terhadap lingkungan orang itu sendiri. Gagasan dasar konsep diri adalah bahwa kepemilikan seseorang 
menunjukkan dan mencerminkan identitas mereka).

4. Faktor Psikologis

Pilihan pembelian seseorang dipengaruhi oleh empat faktor psikologis utama: Motivasi (seseorang senantiasa mempunyai banyak kebutuhan. Kebutuhan menjadi motif ketika kebutuhan itu mencapai tingkat intensitas yang kuat. Motif atau dorongan adalah kebutuhan dengan tekanan kuat yang mengarahkan seseorang mencari kepuasan), Persepsi (proses di mana orang memilih, mengatur dan menginterprestasikan informasi untuk membentuk gambaran dunia yang berarti), Pembelajaran/learning

(menggambarkan perubahan dalam perilaku seseorang yang timbul dari pengalaman) serta Keyakinan dan Sikap (melalui pelaksanaan dan pembelajaran, seseorang mendapatkan keyakinan dan sikap. Keyakinan adalah pikiran deskriptif yang dimiliki seseorang tentang sesuatu. Sikap menggambarkan evaluasi, perasaan dan tendensi yang relatif konsisten dari seseorang terhadap sebuah objek atau ide).

\section{$\underline{\text { Kerangka Pemikiran }}$}

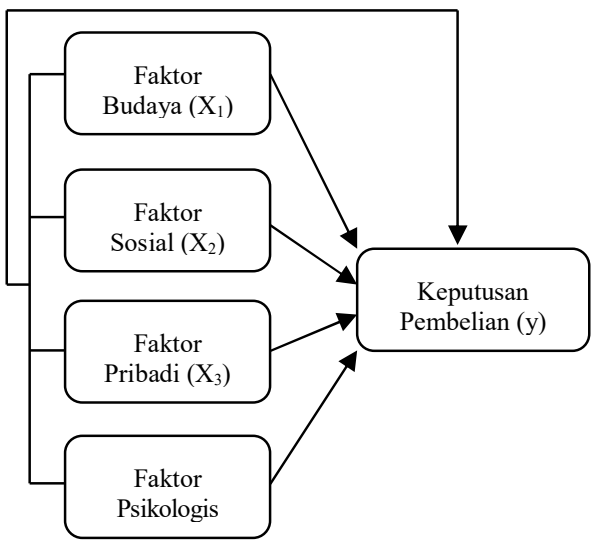

$\underline{\text { Hipotesis }}$

Menurut Kuncoro (2013: 59), hipotesis merupakan jawaban sementara yang disusun oleh peneliti, yang kemudian akan diuji kebenarannya melalui penelitian yang dilakukan. Adapun hipotesis dalam penelitian ini adalah:

1. Faktor budaya, sosial, pribadi dan psikologis secara bersama-sama mempengaruhi perilaku konsumsen dalam pengambilan keputusan pembelian produk roti isi krim durian (jordan bakery) di Desa Rantau Sialang Kecamatan Sungai Keruh.

2. Faktor budaya, sosial, pribadi dan psikologis secara parsial mempengaruhi perilaku konsumsen dalam pengambilan keputusan pembelian produk roti isi krim durian (jordan bakery) di Desa Rantau Sialang Kecamatan Sungai Keruh.

\section{METODOLOGI PENELITIAN}

\section{$\underline{\text { Desain Penelitian }}$}

Menurut tingkat eksplanasi atau tingkat penjelasan, jenis penelitian yang dilakukan dalam penelitian ini adalah penelitian asosiatif. Sinambela (2014: 13) mengemukakan bahwa penelitian asosiatif adalah penelitian yang minimal mempertentangkan dua variabel yang dihubungkan antara satu variabel dengan variabel yang lain.

Penelitian ini bertujuan untuk menganalisis faktor budaya $\left(\mathrm{X}_{1}\right)$, faktor sosial $\left(\mathrm{X}_{2}\right)$, faktor pribadi $\left(\mathrm{X}_{3}\right)$ dan faktor psikologis $\left(\mathrm{X}_{4}\right)$ terhadap keputusan pembelian (Y). Dengan demikian desain penelitian yang 
digunakan adalah korelasional. Penelitian ini mencoba mengumpulkan fakta dan data yang berkaitan dengan variabel yang menjadi perhatian dalam penelitian. Dengan penelitian ini dapat diketahui bagaimana faktor budaya, faktor sosial, faktor pribadi dan faktor psikologis mempengaruhi keputusan pembelian produk, baik secara bersama-sama maupun secara parsial.

\section{$\underline{\text { Populasi dan Sampel }}$}

Dalam setiap penelitian harus terlebih dahulu ditentukan populasi yang akan diteliti. Menurut Sugiyono (2019: 126), populasi adalah wilayah generalisasi yang terdiri atas: obyek/subyek yang mempunyai kuantitas dan karakteristik tertentu yang ditetapkan oleh peneliti untuk dipelajari dan kemudian ditarik kesimpulannya. McClave dkk (2011: 6) mengemukakan bahwa populasi adalah sekumpulan unit (biasanya orang, objek, transaksi, atau kejadian) yang ingin kita pelajari. Populasi dalam penelitian ini adalah seluruh penduduk di Desa Rantau Sialang Kecamatan Sungai Keruh yang berjumlah 3.705 jiwa.

Selanjutnya Sekaran dan Bougie (2017: 54) mengemukakan bahwa sampel adalah sebagian dari populasi yang terdiri atas sejumlah anggota yang dipilih dari populasi. Karena berbagai alasan, tidak semua hal yang ingin dijelaskan atau diramalkan atau dikendalikan dapat diteliti. Suryabrata (2010: 35) menyatakan bahwa penelitian ilmiah boleh dikatakan hampir selalu hanya dilakukan terhadap sebagian saja dari hal-hal yang sebenarnya mau diteliti. Jadi penelitian hanya dilakukan terhadap sampel, tidak terhadap populasi. Dengan mempelajari sampel, peneliti mampu menarik kesimpulan yang dapat digeneralisasikan terhadap populasi ketertarikan (yang diminati). Sampel dalam penelitian ini menggunakan Rumus Slovin dalam Wahyudi (2017: 17) dengan menghasilkan sampel sebanyak 97 orang (tingkat kesalahan penetapan sampel 10\%).

\section{$\underline{\text { Sumber dan Teknik Pengumpulan Data }}$}

Penelitian ini menggunakan data primer dan data sekunder. Menurut Hasan (2013: 33), data primer adalah data yang diperoleh atau dikumpulkan oleh orang yang melakukan penelitian atau yang bersangkutan yang memerlukannya. Kemudian Zikmund dan Babin (2011: 266) mengemukakan bahwa data sekunder adalah data yang sudah dikumpulkan sebelumnya untuk tujuan tertentu, selain tujuan yang ada sekarang. Data primer disebut juga data asli atau data baru, sedangkan data sekunder disebut juga data tersedia.

Teknik pengumpulan data yang digunakan dalam penelitian ini adalah kuesioner dan dokumentasi. Kuesioner yang disebarkan bersifat tertutup di mana setiap pertanyaan/pernyataan sudah disediakan alternatif jawabannya, sehingga responden hanya memilih salah satu alternatif jawaban yang dianggap sesuai dengan pertanyaan/ pernyataan. Pertanyaan/pernyataan dalam kuesioner disusun dengan menggunakan skala likert yang dikembangkan oleh Rensis Likert (Cooper dan Schindler, 2006: 40). Dokumentasi yang dimaksud dalam penelitian ini adalah dokumen resmi yang didapatkan dari Kepala Desa 
Rantau Sialang Kecamatan Sungai Keruh.

Metode Analisis

Data dalam penelitian ini diuji kualitasnya dengan uji validitas dan uji reliabilitas. Fasilitas perangkat lunak IBM SPSS Statistics 24 digunakan untuk melakukan uji validitas dan uji reliabilitas. Dalam penelitian ini, data dianalisa menggunakan metode analisis kuantitatif dengan tahapan analisis regresi berganda, analisis determinan, uji serentak dan uji parsial.

\section{HASIL DAN PEMBAHASAN}

\section{$\underline{\text { Pengujian Kuesioner }}$}

\section{Pengujian Validitas Data}

Nilai $r_{\text {tabel }}$ uji dua sisi dengan taraf nyata $(\alpha)=5 \%$ dan $n=97$ yaitu 0,202. Menurut Priyatno (2010: 95), kriteria pengujian validitas data adalah sebagai berikut :

a. Jika $r_{\text {hitung }} \geq \mathrm{r}_{\text {tabel }}$ (uji 2 sisi dengan sig. 0,05), maka instrumen atau item-item pertanyaan dinyatakan valid

b. Jika $r_{\text {hitung }}<r_{\text {tabel }}$ (uji 2 sisi dengan sig. 0,05), maka

instrumen atau item-item pertanyaan dinyatakan tidak valid.

Dari hasil uji validitas dengan menggunakan metode cronbach's alpha, untuk item-item variabel faktor budaya $\left(\mathrm{X}_{1}\right)$, faktor sosial $\left(\mathrm{X}_{2}\right)$, faktor pribadi $\left(\mathrm{X}_{3}\right)$, faktor psikologis $\left(\mathrm{X}_{4}\right)$, keputusan pembelian (Y) dapat dilihat pada tabel 1 berikut ini :
Tabel 1

Hasil Uji Validitas

\begin{tabular}{|c|c|c|c|c|}
\hline No. & Item & rhitung & $\begin{array}{c}\text { rtabel } \\
(\alpha=5 \%)\end{array}$ & Hasil Uji \\
\hline 1. & $\mathrm{X}_{1 \_1}$ & 0,82 & 0,202 & Valid \\
\hline 2. & $\mathrm{X}_{1 \_} 2$ & 0,50 & 0,202 & Valid \\
\hline 3. & $\mathrm{X}_{1 \_} 3$ & 0,91 & 0,202 & Valid \\
\hline 4. & $\mathrm{X} 21$ & 0,78 & 0,202 & Valid \\
\hline 5. & $\mathrm{X} 2 \_2$ & 0,85 & 0,202 & Valid \\
\hline 6. & $\mathrm{X} 2 \_3$ & 0,91 & 0,202 & Valid \\
\hline 7. & X3_1 & 0,47 & 0,202 & Valid \\
\hline 8. & X3_2 & 0,92 & 0,202 & Valid \\
\hline 9. & X3 3 & 0,84 & 0,202 & Valid \\
\hline 10. & $\mathrm{X} 34$ & 0,80 & 0,202 & Valid \\
\hline 11. & $\times 35$ & 0,77 & 0,202 & Valid \\
\hline 12. & X3_6 & 0,92 & 0,202 & Valid \\
\hline 13. & X3_7 & 0,80 & 0,202 & Valid \\
\hline 14. & X4_1 & 0,80 & 0,202 & Valid \\
\hline 15. & $\mathrm{X} 4 \_2$ & 0,64 & 0,202 & Valid \\
\hline 16. & $\mathrm{X} 4 \_3$ & 0,83 & 0,202 & Valid \\
\hline 17. & X4_4 & 0,52 & 0,202 & Valid \\
\hline 18. & $\times 455$ & 0,59 & 0,202 & Valid \\
\hline 19. & $\mathrm{y} 1$ & 0,69 & 0,202 & Valid \\
\hline 20. & $\mathrm{y} 2$ & 0,52 & 0,202 & Valid \\
\hline 21. & $\mathrm{y} 3$ & 0,72 & 0,202 & Valid \\
\hline
\end{tabular}

Sumber : Hasil Pengolahan Data dengan IBM SPSS Statistics 24

Dari hasil pengolahan data menggunakan bantuan program IBM SPSS Statistics 24 menunjukkan hasil uji validitas dari setiap item pertanyaan/ pernyataan variabel faktor budaya $\left(\mathrm{X}_{1}\right)$, faktor sosial $\left(\mathrm{X}_{2}\right)$, faktor pribadi $\left(\mathrm{X}_{3}\right)$, faktor psikologis $\left(\mathrm{X}_{4}\right)$, keputusan pembelian $(\mathrm{Y})$ tersebut valid pada taraf nyata $(\alpha)=5 \%$ yang berarti semua item pertanyaan/pernyataan yang ada pada instrumen tersebut dapat dijadikan sebagai alat ukur yang valid dalam analisis selanjutnya.

\section{Pengujian Reliabilitas Data}

Dalam melakukan pengujian reliabilitas, digunakan metode cronbachs alpha. Pengujian reliabilitas instrumen dalam penelitian ini menggunakan batasan nilai kritis 
product moment $(\alpha)$ sebesar 0,6 (Priyatno, 2010: 98) dengan ketentuan sebagai berikut :

a. Jika cronbachs alpha item $\geq 0,6$, maka butir dari pernyata an (variabel) tersebut adalah reliabel.

b. Jika croncbachs alpha item $<0,6$, maka butir dari pernyataan (variabel) tersebut adalah tidak reliabel.

Berdasarkan hasil uji reliabilitas dengan menggunakan metode cronbachs alpha untuk item-item variabel faktor budaya $\left(\mathrm{X}_{1}\right)$, faktor sosial $\left(\mathrm{X}_{2}\right)$, faktor pribadi $\left(\mathrm{X}_{3}\right)$, faktor psikologis $\left(\mathrm{X}_{4}\right)$, keputusan pembelian (Y) dapat dilihat pada tabel 2. berikut ini :

Tabel 2

Hasil Uji Reliabilitas

\begin{tabular}{|l|c|c|c|}
\hline \multicolumn{1}{|c|}{ Item } & $\begin{array}{c}\text { Cronbach's } \\
\text { Alpha }\end{array}$ & Alpha & $\begin{array}{c}\text { Hasil } \\
\text { Uji }\end{array}$ \\
\hline $\begin{array}{l}\text { Faktor } \\
\text { Budaya }\end{array}$ & 0,834 & 0,6 & Reliabel \\
\hline $\begin{array}{l}\text { Faktor } \\
\text { Sosial }\end{array}$ & 0,925 & 0,6 & Reliabel \\
\hline $\begin{array}{l}\text { Faktor } \\
\text { Pribadi }\end{array}$ & 0,914 & 0,6 & Reliabel \\
\hline $\begin{array}{l}\text { Faktor } \\
\text { Psikologis }\end{array}$ & 0,840 & 0,6 & Reliabel \\
\hline $\begin{array}{l}\text { Keputusan } \\
\text { Pembelian }\end{array}$ & 0,775 & 0,6 & Reliabel \\
\hline
\end{tabular}

Sumber : Hasil Pengolahan Data dengan IBM SPSS Statistics 24

Dari hasil pengolahan data menggunakan bantuan program IBM SPSS Statistics 24 menunjukkan bahwa semua variabel yang akan digunakan dalam penelitian ini mempunyai nilai cronbach's alpha di atas 0,6. Dari hasil tersebut menunjukkan bahwa semua indikator tersebut dapat dijadikan sebagai alat ukur yang reliabel dalam analisis selanjutnya $\underline{\text { Analisis Regresi Berganda }}$

Analisis regresi berganda (multiple regression analysis) digunakan untuk melihat besaran pengaruh faktor budaya $\left(\mathrm{X}_{1}\right)$, faktor sosial $\left(\mathrm{X}_{2}\right)$, faktor pribadi $\left(\mathrm{X}_{3}\right)$, faktor psikologis $\left(\mathrm{X}_{4}\right)$ terhadap keputusan pembelian (Y). Hasil pengolahan data dengan menggunakan IBM SPSS Statistics 24 ditampilkan dalam tabel sebagai berikut :

Tabel 3

Hasil Analisa Regresi

\begin{tabular}{l|l|r|r|r|}
\hline \multirow{2}{*}{ Model } & \multicolumn{2}{|c|}{$\begin{array}{c}\text { Unstandardized } \\
\text { Coefficients }\end{array}$} & \multirow{2}{*}{} \\
\cline { 2 - 4 } & \multicolumn{1}{|c|}{ B } & \multicolumn{1}{|c|}{$\begin{array}{c}\text { Std. } \\
\text { Error }\end{array}$} & \multicolumn{1}{c|}{ t } & Sig. \\
\hline (Constant) & 3,527 &, 434 & 8,123 &, 000 \\
\hline $\begin{array}{l}\text { Faktor } \\
\text { Budaya }\end{array}$ &,- 010 &, 085 &,- 119 &, 905 \\
\hline Faktor Sosial &, 327 &, 069 & 4,771 &, 000 \\
\hline $\begin{array}{l}\text { Faktor } \\
\text { Pribadi }\end{array}$ &, 363 &, 034 & 10,631 &, 000 \\
\hline $\begin{array}{l}\text { Faktor } \\
\text { Psikologis }\end{array}$ &,- 218 &, 080 & $-2,713$ &, 008 \\
\hline
\end{tabular}

Dari hasil regresi berganda dapat digambarkan persamaan regresi bergandanya sebagai berikut :

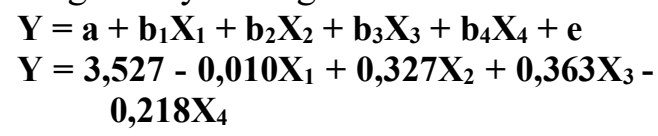

Dari persamaan regresi berganda di atas dapat dijelaskan sebagai berikut:

- Konstanta sebesar 3,527; artinya jika faktor budaya $\left(\mathrm{X}_{1}\right)$, faktor sosial $\left(\mathrm{X}_{2}\right)$, faktor pribadi $\left(\mathrm{X}_{3}\right)$ dan faktor psikologis $\left(\mathrm{X}_{4}\right)$ nilainya adalah 0 , maka keputusan pembelian (Y) nilainya adalah 3,527 .

- Nilai koefisien variabel faktor budaya $\left(\mathrm{X}_{1}\right)$ sebesar $-0,010$; artinya jika variabel independen lain nilainya tetap dan faktor budaya $\left(\mathrm{X}_{1}\right)$ mengalami kenaikan 1 satuan 
skor, maka keputusan pembelian (Y) mengalami penurunan sebesar 0,010 satuan skor. Koefisien bernilai negatif artinya terjadi hubungan negatif antara faktor budaya $\left(\mathrm{X}_{1}\right)$ dengan keputusan pembelian $(\mathrm{Y}), \quad$ semakin meningkatnya faktor budaya $\left(\mathrm{X}_{1}\right)$ maka semakin menurunnya keputusan pembelian (Y).

- Nilai koefisien variabel faktor sosial $\left(\mathrm{X}_{2}\right)$ sebesar 0,327; artinya jika variabel independen lain nilainya tetap dan faktor sosial $\left(\mathrm{X}_{2}\right)$ mengalami kenaikan 1 satuan skor, maka keputusan pembelian (Y) mengalami peningkatan sebesar 0,327 satuan skor. Koefisien bernilai positif artinya terjadi hubungan positif antara faktor sosial $\left(\mathrm{X}_{2}\right)$ dengan keputusan pembelian (Y), semakin meningkatnya faktor sosial $\left(\mathrm{X}_{2}\right)$ maka semakin meningkat pula keputusan pembelian (Y).

- Nilai koefisien variabel faktor pribadi $\left(\mathrm{X}_{3}\right)$ sebesar 0,363 ; artinya jika variabel independen lain nilainya tetap dan faktor pribadi $\left(\mathrm{X}_{3}\right)$ mengalami kenaikan 1 satuan skor, maka keputusan pembelian (Y) mengalami peningkatan sebesar 0,363 satuan skor. Koefisien bernilai positif artinya terjadi hubungan positif antara faktor pribadi $\left(\mathrm{X}_{3}\right)$ dengan keputusan pembelian $(\mathrm{Y}), \quad$ semakin meningkatnya faktor pribadi $\left(\mathrm{X}_{3}\right)$ maka semakin meningkat pula keputusan pembelian (Y).

- Nilai koefisien variabel faktor psikologis $\left(\mathrm{X}_{4}\right)$ sebesar -0,218; artinya jika variabel independen lain nilainya tetap dan faktor psikologis $\left(\mathrm{X}_{4}\right)$ mengalami kenaikan 1 satuan skor, maka keputusan pembelian
(Y) mengalami penurunan sebesar 0,218 satuan skor. Koefisien bernilai negatif artinya terjadi hubungan negatif antara faktor psikologis $\left(\mathrm{X}_{4}\right)$ dengan keputusan pembelian (Y), semakin meningkatnya faktor psikologis $\left(\mathrm{X}_{4}\right)$ maka semakin menurunnya keputusan pembelian (Y).

\section{$\underline{\text { Uji Koefisien Determinan }}$}

Untuk menjawab pengaruh faktor budaya $\left(\mathrm{X}_{1}\right)$, faktor sosial $\left(\mathrm{X}_{2}\right)$, faktor pribadi $\left(\mathrm{X}_{3}\right)$, faktor psikologis $\left(\mathrm{X}_{4}\right)$ secara bersama-sama terhadap keputusan pembelian (Y), yaitu menggunakan uji koefisien determinan sebagai berikut:

Tabel 4

Model Summary

\begin{tabular}{|c|c|c|c|c|}
\hline Model & $\mathrm{R}$ & $\begin{array}{c}\mathrm{R} \\
\text { Square } \\
\end{array}$ & $\begin{array}{c}\text { Adjusted R } \\
\text { Square }\end{array}$ & $\begin{array}{l}\text { Std. Error of } \\
\text { the Estimate }\end{array}$ \\
\hline 1 &, $930^{\mathrm{a}}$ & ,864 &, 858 & ,41501 \\
\hline
\end{tabular}

Dari tabel Model Summary di atas, terlihat bahwa nilai koefisien determinan (R Square) adalah sebesar $0,864(86,4 \%)$. Hal ini berarti bahwa keputusan pembelian (Y) dapat dijelaskan oleh faktor budaya $\left(\mathrm{X}_{1}\right)$, faktor sosial $\left(\mathrm{X}_{2}\right)$, faktor pribadi $\left(\mathrm{X}_{3}\right)$, faktor psikologis $\left(\mathrm{X}_{4}\right)$ sebesar $86,4 \%$, sedangkan sisanya $13,6 \%$ dijelaskan oleh faktor lain yang tidak termasuk dalam penelitian ini.

\section{$\underline{\text { Uji Hipotesis }}$}

\section{Uji Serentak (Uji F)}

Menurut Priyatno (2010: 67), jika $F_{\text {hitung }} \geq \mathrm{F}_{\text {tabel, }}$, maka $\mathrm{H}_{0}$ ditolak dan $\mathrm{H}_{\mathrm{a}}$ diterima, jika $\mathrm{F}_{\text {hitung }}<\mathrm{F}_{\text {tabel, }}$, maka 
$\mathrm{H}_{0}$ diterima dan $\mathrm{H}_{\mathrm{a}}$ ditolak. Sedangkan $\mathrm{F}_{\text {tabel }}$ dengan taraf nyata $(\alpha)=5 \%$ dengan penyebut $\mathrm{dk}=(\mathrm{n}-\mathrm{k}-\mathrm{l})=(97-4-1)$ dan pembilang $(\mathrm{k}=4)$ adalah sebesar \pm 2,471 .

Tabel 5

ANOVA

\begin{tabular}{|c|c|c|c|c|c|}
\hline Model & $\begin{array}{l}\text { Sum of } \\
\text { Squares }\end{array}$ & Df & $\begin{array}{c}\text { Mean } \\
\text { Square }\end{array}$ & $\mathrm{F}$ & Sig. \\
\hline 1 Regression & 100,81 & 4 & 25,204 & 146,3 &, $000^{\mathrm{b}}$ \\
\hline Residual & 15,84 & 92 &, 172 & & \\
\hline Total & 116,66 & 96 & & & \\
\hline \multicolumn{6}{|c|}{$\begin{array}{l}\text { a. Dependent Variable: keputusan pembelian } \\
\text { b. Predictors: (Constant), faktor psikologis, faktor } \\
\text { pribadi, faktor sosial, faktor budaya }\end{array}$} \\
\hline
\end{tabular}

Berdasarkan pada tabel di atas, maka dapat dilihat bahwa $F_{\text {hitung }}$ untuk variabel faktor budaya $\left(\mathrm{X}_{1}\right)$, faktor sosial $\left(\mathrm{X}_{2}\right)$, faktor pribadi $\left(\mathrm{X}_{3}\right)$, faktor psikologis $\left(\mathrm{X}_{4}\right)$ terhadap keputusan pembelian (Y) adalah sebesar 146,337, maka $F_{\text {hitung }}(146,337)>F_{\text {tabel }}(2,471)$ yang berarti bahwa ada pengaruh faktor budaya $\left(\mathrm{X}_{1}\right)$, faktor sosial $\left(\mathrm{X}_{2}\right)$, faktor pribadi $\left(\mathrm{X}_{3}\right)$, faktor psikologis $\left(\mathrm{X}_{4}\right)$ secara bersama-sama terhadap keputusan pembelian (Y), sehingga $\mathrm{H}_{0}$ ditolak dan $\mathrm{H}_{\mathrm{a}}$ diterima.

Nilai signifikan (Sig F) adalah sebesar 0,000 yang berarti Sig F $(0,000)$ $<\alpha \quad(0,05) . \quad$ Hal tersebut menggambarkan bahwa ada pengaruh yang signifikan faktor budaya $\left(\mathrm{X}_{1}\right)$, faktor sosial $\left(\mathrm{X}_{2}\right)$, faktor pribadi $\left(\mathrm{X}_{3}\right)$, faktor psikologis $\left(\mathrm{X}_{4}\right)$ secara bersamasama terhadap keputusan pembelian (Y).

Untuk lebih jelasnya, berikut ini disajikan gambar kurva uji $\mathrm{F}$ atas pengaruh faktor budaya $\left(\mathrm{X}_{1}\right)$, faktor sosial $\left(\mathrm{X}_{2}\right)$, faktor pribadi $\left(\mathrm{X}_{3}\right)$, faktor psikologis $\left(\mathrm{X}_{4}\right)$ secara bersama-sama terhadap keputusan pembelian (Y) adalah sebagai berikut:

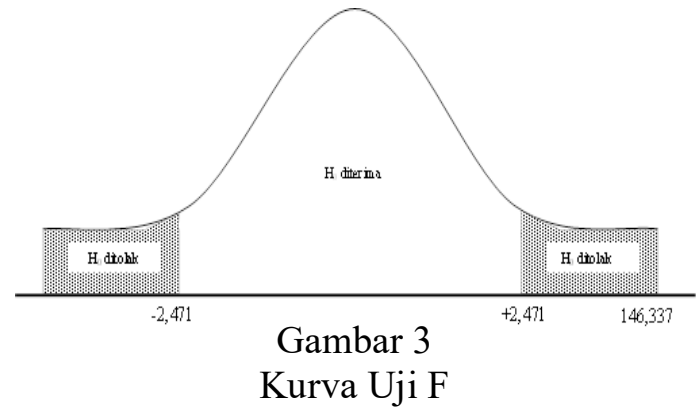

Dari hasil perhitungan uji $\mathrm{F}$ di atas, menggambarkan bahwa pada dasarnya faktor budaya, faktor sosial, faktor pribadi dan faktor psikologis memberikan pengaruh yang cukup besar terhadap keputusan pembelian produk roti isi krim durian (Jordan Bakery) di Desa Rantau Sialang Kecamatan Sungai Keruh.

Hasil penelitian ini menjawab hipotesis penelitian ini dan juga sesuai dengan pendapat Kotler dan Amstrong (2008: 159) yang menyatakan pembelian konsumen sangat dipengaruhi oleh karakteristik budaya, sosial, pribadi dan psikologis. Hasil penelitian ini juga sejalan dengan pernyataan Abdullah dan Tantri (2012: 134) bahwa perilaku pembeli dipengaruhi oleh empat faktor utama: budaya, sosial, pribadi dan psikologis.

Uji Parsial (Uji t)

Menurut Priyatno (2010: 68), jika thitung $\geq t_{\text {tabel}}$, maka $\mathrm{H}_{0}$ ditolak dan $\mathrm{H}_{\mathrm{a}}$ diterima, sedangkan jika $\mathrm{t}_{\text {hitung }}<\mathrm{t}_{\text {tabel }}$, maka $\mathrm{H}_{0}$ diterima dan $\mathrm{H}_{\mathrm{a}}$ ditolak, jika sig $\mathrm{t}>0,05$, maka tidak ada pengaruh yang signifikan dan jika sig $\mathrm{t} \leq 0,05$, maka data tersebut ada pengaruh yang signifikan.

Untuk menjelaskan pengaruh faktor budaya $\left(\mathrm{X}_{1}\right)$, faktor sosial $\left(\mathrm{X}_{2}\right)$, faktor pribadi $\left(\mathrm{X}_{3}\right)$, faktor psikologis $\left(\mathrm{X}_{4}\right)$ secara parsial terhadap keputusan pembelian $(\mathrm{Y})$, digunakan uji hipotesis $\mathrm{t}$ 
dengan hasil pengolahan data pada tabel

3 .

Nilai tabel dengan taraf nyata $(\alpha)$

$=5 \%, \mathrm{df}=(\mathrm{n}-2)=(97-2)$ adalah sebesar

$+1,985$, maka dapat digambarkan bahwa:

1. Secara parsial faktor budaya (budaya, subbudaya dan kelas sosial) tidak berpengaruh secara signifikan terhadap Keputusan pembelian (Y) produk roti isi krim durian (Jordan Bakery) di Desa Rantau Sialang Kecamatan Sungai Keruh.

Hasil penelitian ini sesuai dengan pengamatan di lapangan. Produk roti isi krim durian (Jordan Bakery) bisa dinikmati oleh semua warga tanpa melihat kelas sosialnya. Namun demikian, hasil penelitian ini berbeda dengan hasil penelitian sebelumnya yang dilakukan Umar Khasan yang menyimpulkan bahwa faktor-faktor yang mempengaruhi pengambilan keputusan pembelian white coffee adalah budaya, tingkat pendidikan, usia dan jenis kelamin.

2. Secara parsial faktor sosial (kelompok acuan, keluarga, peran dan status), faktor pribadi (usia dan tahap siklus hidup, pekerjaan, situasi ekonomi, gaya hidup, kepribadian dan konsep diri) dan faktor psikologis (motivasi, persepsi, pembelajaran, keyakinan dan sikap) berpengaruh secara signifikan terhadap keputusan pembelian produk roti isi krim durian (Jordan Bakery) di Desa Rantau Sialang Kecamatan Sungai Keruh. Kondisi ini sesuai dengan penelitian yang dilakukan oleh Hendri Wijaya, Yeni Marsih dan Rini Anggraini yang menyatakan bahwa ada pengaruh yang bermakna (signifikan) antara faktor psikologis dengan keputusan pembelian. Perbedaannya dengan penelitian yang saya lakukan adalah keputusan pembelian tidak hanya dipengaruhi oleh faktor psikologis saja, namun secara parsial juga dipengaruhi oleh faktor sosial dan faktor pribadi.

Begitu juga dengan hasil penelitian yang dilakukan oleh Suprihati dan Wikan Budi Utami yang menyimpulkan bahwa tidak ada perbedaan yang nyata antara golongan umur, pendidikan, pekerjaan dan faktor gengsi terhadap perilaku konsumen dalam keputusan pembelian mobil pribadi. Hanya ada perbedaan yang nyata antara pendapatan terhadap perilaku konsumen dalam keputusan pembelian mobil pribadi. Penelitian yang dilakukan menunjukkan bahwa faktor sosial, pribadi dan psikologis secara umum mempengaruhi keputusan pembelian, sedangkan Suprihati dan Wikan Budi Utami lebih khusus meneliti bahwa keputusan pembelian dipengaruhi oleh golongan umur, pendidikan, pekerjaan, faktor gengsi dan pendapatan.

Semakin dikenalnya produk roti isi krim durian (Jordan Bakery) di Desa Rantau Sialang sebagai akibat dari persepsi dan keyakinan atas produk tersebut, sehingga akan menimbulkan image terhadap penikmatnya. Pelaku usaha yang sangat memperhatikan konsumennya, akan dapat menimbulkan nilai emosional pada diri konsumen, dimana akan timbul perasaan positif pada saat membeli atau mengonsumsi produk tersebut.

Pengaruh dari lingkungan masyarakat terhadap produk roti isi krim durian biasanya akan muncul ketika lingkungan tempat tinggal 
memiliki kepercayaan terhadap produk tersebut. Keluarga memiliki pengaruh yang sangat besar dalam keputusan pembelian suatu produk. Jordan Bakery hendaknya selalu melakukan riset untuk mengetahui perkembangan dan keinginan konsumen terhadap produk roti isi krim durian.

\section{KESIMPULAN}

Berdasarkan hasil penelitian dan pembahasan, dapat simpulkan bahwa keputusan pembelian produk roti isi krim durian (Jordan Bakery) di Desa Rantau Sialang Kecamatan Sungai Keruh dipengaruhi secara bersamasama oleh faktor budaya, faktor sosial, faktor pribadi dan faktor psikologis. Akan tetapi secara parsial hanya dipengaruhi secara signifikan oleh faktor sosial, faktor pribadi dan faktor psikologis.

\section{DAFTAR PUSTAKA}

Abdullah, Thamrin \& Francis Tantri. 2012. Manajemen Pemasaran. PT. RajaGrafindo Persada, Jakarta.

Assauri, Sofjan. 2010. Manajemen Pemasaran, Dasar, Konsep dan Strategi (Edisi 1, Cetakan Kesepuluh). PT. RajaGrafindo Persada, Jakarta.

Cooper, Donald R. \& Pamela S. Schindler. 2006. Metode Riset Bisnis (Volume 2, Edisi 9). Media Global Edukasi, Jakarta.

Daryanto. 2011. Sari Kuliah Manajemen Pemasaran. Satu Nusa, Bandung.

Hasan, M. Iqbal. 2013. Pokok-pokok Materi Statistik 1 (Statistik
Deskriptif). PT. Bumi Aksara, Jakarta:

Khasan, Umar. 2018. Analisis Faktorfaktor yang Mempengaruhi Perilaku Konsumen dalam Pengambilan Keputusan Pembelian White Coffee. Jurnal Cakrawala, Volume 12 Nomor 2, 157-161.

Kotler, Philip \& Gary Armstrong. 2008. Prinsip-prinsip Pemasaran (Edisi 12, Jilid 1). Erlangga, Jakarta.

Kotler, Philip \& Kevin Lane Keller. 2009. Manajemen Pemasaran (Edisi 13, Jilid 1). Erlangga, Jakarta.

Kuncoro, Mudrajad. 2013. Metode Riset untuk Bisnis \& Ekonomi (Edisi 4). Erlangga, Jakarta.

McClave, James T., P. George Bendon \& Terry Sincich. 2011. Statistik untuk Bisnis dan Ekonomi (Edisi Kesebelas, Jilid 1). Erlangga, Jakarta.

Peter, J. Paul \& Jerry C. Olson. 2014. Perilaku Konsumen dan Strategi Pemasaran (Edisi 9, Buku 1). Salemba Empat, Jakarta.

Priyatno, Duwi. 2010. Paham Analisa Statistik Data dengan SPSS. PT. Buku Seru, Jakarta.

Sekaran, Uma \& Roger Bougie. 2017. Metode Penelitian untuk Bisnis (Edisi 6, Buku 2). Salemba Empat, Jakarta.

Shinta, Agustina. 2011. Manajemen Pemasaran. Universitas Brawijaya (UB) Press, Malang:

Sinambela, Lijan Poltak. 2014. Metode Penelitian Kuantitatif untuk Bidang Ilmu Administrasi, Kebijakan Publik, Ekonomi, Sosiologi, Komunikasi dan Ilmu Sosial Lainnya. Graha Ilmu, Yogyakarta. 
Sugiyono. 2019. Metode Penelitian Kuantitatif Kualitatif dan $R \& D$ (Edisi Kedua, Cetakan ke-1). Alfabeta, Bandung.

Sumarwan, Ujang. 2014. Perilaku Konsumen, Teori dan Penerapannya dalam Pemasaran (Edisi Kedua, Cetakan Kedua). Ghalia Indonesia, Bogor.

Suprihati \& Wikan Budi Utami. 2015. Analisis Faktor-faktor yang Mempengaruhi Perilaku Konsumen dalam Keputusan Pembelian Mobil Pribadi di Kelurahan Gonilan Kabupaten Sukoharjo. Jurnal Paradigma, Vol. 13, No. 01, 104-116.

Suryabrata, Sumadi. 2010. Metodologi Penelitian. PT. RajaGrafindo Persada, Jakarta.

Tjiptono, Fandy. 2019. Strategi Pemasaran (Edisi 4). Andi, Yogyakarta.

Wahyudi, Setyo Tri. 2017. Statistika Ekonomi, Konsep, Teori dan Penerapan. Universitas Brawijaya (UB) Press Malang.

Wijaya, Hendry, Yeni Marsih \& Rini Anggraini. 2018. Pengaruh Faktor Psikologis terhadap Keputusan Pemilihan Biro Perjalanan Umroh pada PT. Namirah Angkasa Jayatama (NAJA) Tour \& Travel Sekayu. Jurnal Manajemen Kompeten, Vol. 1 No. 1, 29-42.

Zikmund, William G. \& Barry J. Babin. 2011. Menjelajahi Riset Pemasaran (Edisi 10, Buku 1). Salemba Empat, Jakarta. 


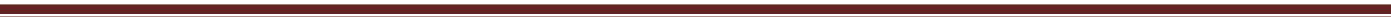
e-ISSN 2685-2977

Jurnal Ekonomika Volume XI Nomor 2 Juni 2020 